\title{
Toward User Interfaces and Data Visualization Criteria for Learning Design of Digital Textbooks
}

\author{
Elena RAILEAN \\ Alexandru Ioan Cuza University of Iasi, Romania \\ Academy of Sciences of Moldova \\ University of European Studies of Moldova \\ e-mail: elenarailean32@gmail.com
}

Received: January 2014

\begin{abstract}
User interface and data visualisation criteria are central issues in digital textbooks design. However, when applying mathematical modelling of learning process to the analysis of the possible solutions, it could be observed that results differ. Mathematical learning views cognition in on the base on statistics and probability theory, graph theory, game theory, cellular automata, neural networks etc. Instead of this, research methodologies in learning design are diversified in behaviourism, cognitive, constructivism and connexionism. Behaviourism aims to promote observable behavior, but placing the responsibility for learning on the shoulders of teachers and/ or textbooks' content. The cognitive and social psychology adds value to the systems theory and place the responsibility to mental structures of students' cognitive systems. Constructivism aims to support multiple perspectives or interpretations of reality, knowledge construction, contextrich, experience-based activities and focused on didactic activities. The connectionism models are based on mental or behavioral phenomena as the emergent processes of interconnected networks of simple units. These trends could be analysed on the base on linear, systems and Meta-Systems approaches. This article is a review of user interface and data visualisation criteria as a demonstration of Meta-Systems Learning Design in Digital Textbooks use and development.
\end{abstract}

Keywords: digital textbook, user interface design, metasystems learning design.

\section{Introduction}

There is a widespread though controversial belief about those digital textbooks has been shaped according to human thinking paradigms. Merril et al. (1996) observed that instructional design is founded on scientific principles verified on empirical data. The author defines instructional design as a technology for the development of learning experiences and environment which promote the acquisition of specific knowledge and skills by students. 
The holistic dynamicity of human thinking paradigms could be analysed as a metareview of the learning design paradigms. Brusilovsky and Peylo (2003, p. 163-164) compare three learning design paradigms: AI-CAI, ITS and AIWBES Paradigm. The first paradigm aims to replace primitive computer artificial instruction in transferring knowledge based on classroom without teacher, including all learning material inside the system, most often presentation, but also exercise and problems. Curriculum sequencing and intelligent analysed are the most used technologies. The second paradigm aims to support problem solving in context of a classroom with a facilitator or self-study. Instead of AI-CAI paradigm is not required to include the presentation material inside the system, but problems are often included. Moreover, the interactive problem solving support is the core technology. In addition, the AIWBES paradigm aims on comprehensive support in context of impendent self-study, on-line learning and includes rich learning presentations, examples, and problems.

The evolution of learning design paradigms could be compared with trends in mathematical learning theory of optimizing instruction. According to definition, the mathematical learning theory is an attempt to describe and explain behavior in quantitative terms. However, the mathematical learning theories are also depends on learning design paradigms. So, the first learning design theories are based on stimulus-reinforcement processes, discrete parameter stochastic process, changes in probability of occurrence of a response in a small time etc. (Bush and Mosteller, 1951; Norman, 1972; Atkinson, Bayar and Kroters, 1969 etc.).

In all analysed cases, the mathematical learning theory before 1980 view learning as a linear relation between content and user (student). After "interactive learning revolution" (Barker and Tucker, 1990) the mathematical learning theory was focused on "complexity regularization with applications to artificial neural networks" (Barron, 1990); "neural networks for pattern recognition" (Bishop, 1995); "complexity and real computation" (Blum, Cucker, Shub, Smale, 1998); "entropy” (Carl and Stephani, 1990; Edmunds and Triebel, 1996 etc.).

User interface design of learning materials also evolve according to human thinking paradigms. There are three main paradigms: teacher-centered, user-centered and blended design methodologies. According to Huba and Freed (2000) in teacher-centered knowledge paradigm, the knowledge is transmitted from professor to students; students passively receive information; emphasis is on acquisition of knowledge outside the context in which it will be used; professor's role is to be primary information giver and primary evaluator; teaching and assessment are separate; assessment is used to monitor learning; emphasis is on right answers; designed learning is accessed indirectly through the use of objectively scored tests and focus is on single discipline. Instead of teacher-centered paradigm, in learner-centered paradigm students construct knowledge through gathering and synthezing information and integrating it with the general skills of injury, communication, critical thinking and so on. Students are actively involved in learning. Emphasis is on using and communicating knowledge effectively; professor's role is to coach and facilitate learning in common learning projects; teaching and assessing are intertwined; assessment is used to promote and diagnose learning; desired learning is assessed directly through papers, projects, performances, portfolios, and the like; the approach is 
compatible with interdisciplinary investigation. According to Darrow (2012) blended teaching is a combination of flexibility of time; online discussions boards; Web 2.0 in assessment; personalised learning; ongoing review of student data; individual, group or collaborative meeting; digital curriculum; graded online etc.

Data visualisation is another important concept in learning design. Few (2013) defines data visualization as the graphical display of abstract information for two purposes: sense-making (also called data analysis) and communication. This approach could be used to identify the most important criteria for digital textbooks user interface design.

\section{Linear Thinking}

Linear thinking is a process of thought following known cycles or step-by-step progression where a response to a step must be elicited before another step is taken. Various instructional design models of digital textbooks, user interface and data visualization criteria prove the concept of linear thinking, when event $A$ (cause) leads to event $B$ (effect), which leads to $C$, then leads to $D$ etc. and when each step is guided by well-defined educational objectives. Usually, the content is structured in lessons, which are logically integrated. Two methods: computer aided instruction and computer based assessment are used in learning design of digital textbook content. The students must read the content and select one or more versions in multiply-choice items, which consist of a stem and a set of options from distractor and alternatives. Data visualization criteria are very simple: a piece of knowledge, a question related to presented content and summative assessment test at the end of the chapter. Students only read, view or hear the content and choose the correct answer!

The content of digital textbook may include the simulation of a realistic phenomenon, a dangerous experiment, or a situation not readily observable by the user; the tangible manifestation of a theory; the presentation of questions or information followed by questions etc. However, the probability of errors is big: firstly, because the answer can be found in presented material and, secondly, at least one correct answer means the probability of $25 \%$. Moreover, multiply-choice and essay items have many limitations: a high guessing factor, minimalisation of delayed feedback and feedback loop etc. In some cases the textbooks "indicate" whether the response was correct or not, and it also kept a record of the number of attempts, the progress of learning etc., but cannot provide a framework for discussion.

The other example describes the content organised into sequence of events, when the response is reinforced at every trial. Is this a correct way? Skinner prefers that the student constructs his answers rather than relying upon recognition. In characteristic of principle of operant conditioning learning is controlled by rewarding the student after he has made the correct answer. Moreover, Ellsworth and Hedley (1994, p. 45) observed that success at each step was rewarded immediately, although alternative reinforcements were also used.

After the interactive learning revolution the text has added value of hypertext and multimodal text. Hypertext is a text which contains links to other chunks of text (or 
graphical elements) and where learner can jump from anywhere to anywhere while pursuing a chain of thought. The multimodal text is texts which communicate their message using more than one semiotic mode, or channel of communication. Some of the principle communicative components of text are: written or spoken language, intonation, images (photographs, diagrams, drawings), and aspects of images such as colour, sharpness of focus, spatial composition, logos, corporate letterheads, shop or road signs; gestures, facial movements, action etc.

The negative aspects of hypertext for learning were described by Solway (2011). He observed that hypertext disperses and distracts the attention, splintering the reading mind into simple fragments leading it down a coiled labyrinth of links, webs, notes, illustrations, diagrams, sound bites, and animation into a state of intellectual convention. The disparaged linearity threading its way through multiplicity is the aprioristic form of narrative (Solway, 2011, p. 341-342).

Instead of the facts that hypertext don't have a linear structure, the outcomes of the learning using web-based versions of textbooks are estimated also on the base on linear thinking. That said, the web-based versions offered robust multimedia features, many more interactive resources, and various features such as audio readings, interactive timelines, annotated images, interactive activities, and other resources. The web-based textbook is only a supplementary resource in the classroom. The big difference is that many of the features pulled students put of the text into another browser page. Annotating the book text and take notes is the impossible actions. Moreover, these textbooks have two major shortcomings. Firstly, they are not interactive enough. Content can be read/heard in static format or listed page by page as result of various input formats for text, audio or video, such as PDF, WMA, MP3, WMV, and allows multiple interactive functions such as bookmarking, advanced plain-text searching, dynamic text highlighting, etc. Secondly, they are non-adaptive, i.e., students with different performances or learning disabilities get the same material in the same format.

Linear thinking is the common way of thinking, but can destroy projects. Wang and Zhai (2013, p. 1037) notes that linear-thinking mode is a straight, unidirectional and changing-lack thinking way, which in another words means roles of students and teachers. To simplify what we define is teacher-dominating mode, which features passive reception of students followed by traditional practice and exercises of writing, reading and sentence patterns etc.

Data visualization criteria based on linear thinking requires displaying total content, which will be evaluated. However, the digital text is not enhanced with multimedia features so much as vaporized by practical examples. The concrete sense of realised, consistent, and tensile meaning that needs to be laboriously commanded by an attentive, centred mind is scattered and ephemeralised in a kind of dislocation of the reading self. Instead of the fact, that either hypertext or multimodal text doesn't have the linear structure, the learning design principles are norms for linear thinking outcomes: reproductive knowledge. What is the reason? Maybe, is the learning designer' intention to complete the curricula objectives with pedagogical content? Or, maybe, is the fact that students need to have an informed decisions about their pathway? However, the first user interfaces of digital textbooks apply static, dynamic or adaptive hypertext and are designed for the teacher-centered learning environments. 
Brusilovscky, Schwarz and Weber (2003, p. 255) observe that for many designers, the ideal form of educational WWW material seems to be a static electronic copy of a regular textbook: chapter by chapter, page by page, and picture by picture. Such "static textbooks" have two main shortcomings. First, they are not interactive enough, i.e. students can only passively read the educational materials. Second, they are non-adaptive, i.e. students with different abilities, knowledge and background get the same educational material in the same form. Fig. 1 represents a model of user interface of such textbooks.

The psycho-pedagogical issues of this model are the probability of correct answers instead of development the critical thinking and self-regulated skills. Mathematically, the students' probability $q_{\mathrm{n}}$ of making the errors on trial $n$ occurred on trial $k$, is $1-p$ when $n \leq k$ and 0 if $n>k$ and was described using different linear equations. These modes allow evidencing the probability of reproductive knowledge even in models with immediate feedback.

So, if the student answered correctly at the question proposed on display what is the probability that the student really knew the correct answer? What is the architecture of structure of competence? Let us analyse this issue deeper, using the idea of conditional probability. In probability theory, the conditional probability is the probability that an event will occur, when another event is known to occur or to have occurred. The probability $P$ of event $A$ given $B$ is maximum, when $A$ is the maximum probability of event $B$, if $A$ is occurred $P(A / B)$. It is proved that probability of event $A$ given $B$ may or may not be equal to $P(A)$. For this reason, to achieve the total probability of effects of pedagogical scenarios it is important to gain success to event $A$, then to event $B$, and so on. So, to proceed to the next step it is important to pass all the previous steps. So, if the answer is incorrect or machine bugs cannot evaluate correctly the students' answer, the students will need to repeat learning the frame again and again. Finally, these can cause a serious routing loop, which will affect the architecture integrated structure of competence.

\section{Systems Thinking}

While "linear thinking forces use to see one thing at a time, and to progress to whatever is next, which will in turn lead to more" (Risku and Harding, 2013), systems thinking for centuries was overlooked. As was noted by Lazanski (2013) systems thinking emphases looking at wholes rather than parts, and addresses the role of interconnections. It is a circular and focused on closed interdependences. It has precise set of rules that reduced the ambiguities and miscommunications that can crop up when we talk with others about

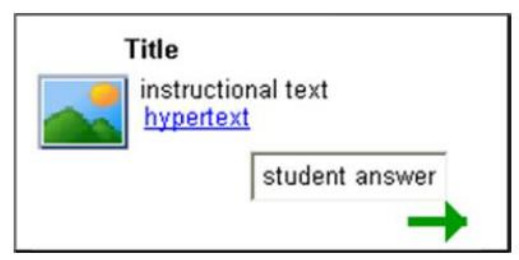

Fig. 1. The model of user interface designed on the base on linear thinking. 
complex issues. It offers causal loop diagrams, which are rich in implications and insight. The modern systems thinking principles are:

- The big picture.

- Long term, short term perspectives.

- Measurable and no measurable data.

- Dynamic, complex and interdependent.

- We are a part of system.

Systems thinking offer an entirely different ways of communications and of working together more productive on understanding and solving complex problem (Lazanski, 2013, p. 293-295).

Brandstädter (2012) has indicated that system thinking is usually investigated by questionnaires, video analysis, or interviews and concept-mapping technique. Let us analyse this idea focusing on answers, which represent the answer provided by the student on the base of teaching machine item. In our case a teaching machine is a knowledge management system which has a database with single or multiply possible answers. The answer could be yes/true, a number, a word or a sentence. As result, the knowledge management system is automatically compared with the correct answer from the database. For example, on display is provided a statement $2+2=\square$ and the learner will write Is this an example of linear or systems thinking? Could these examples be used for problem-solving skills?

Each of the systems works step-by-steps. This means that in case of problem solving the issue can be broken in small steps and the student needs to pass one step in order to perform the next step. For example, if the student passes step $i_{1}$ the current value of his/ her input for next step will be $X_{i}$ and the internal cognitive state will be $S_{i}$ which could be transformed into the output value $Y_{i+1}$ with state $S_{i+1}$ and so on, according to the corresponding functions. Is this possible using knowledge management systems, for example Moodle or ATutor? If yes, what is Data Visualization Criteria and how the user interfaces need to be designed?

Is this useful to apply systems theory in digital textbook use and development? As was observed by Khutorskoi $(2006$, p. 80 ), there are as many theories of the textbook as there are pedagogical systems. Moreover, some models don't allow using of readymade textbooks in the didactic process, such as the Waldorf system of pedagogy and the C. Freinet School. In time when modelling aims to obtain the core structure of competence during learning with/without digital textbooks the design and development of the students' cognitive and behavioural actions are the main issue of systems thinking. The proposed assumption is that correct or incorrect answers need to be proved by feedback from different environments.

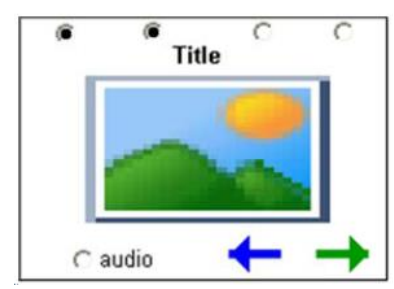

Fig. 2. User interface design for multimedia textbooks. 


\section{Advantages and Disadvantages of Digital Textbooks}

There are many advantages and disadvantages in using of digital textbooks (Table 1). Digital textbooks could be downloaded from different platforms or read online; teacher(s) and student(s) could became authors and distribute easy the textbooks in a digital learning environments. There are also some ways of customisation the online content and distribute this content for better understanding and learning. However, there are some disadvantages related to portability and access, availability, currency, flexibility, navigation and readability, pedagogy, language, costs and security and environmental issues.

Table 1

Advantages and disadvantages of digital textbooks

\begin{tabular}{|c|c|c|}
\hline Criteria & Advantages & Disadvantages \\
\hline $\begin{array}{l}\text { Portability and } \\
\text { access }\end{array}$ & $\begin{array}{l}\text { Anywhere anytime } \\
\text { Mobile devices and PC } \\
\text { Downloadable and online } \\
\text { Cloud-based platforms } \\
\text { Support for students with special } \\
\text { needs and learning disabilities }\end{array}$ & $\begin{array}{l}\text { Internet access, network, bandwidth } \\
\text { Storage requirements for devices } \\
\text { Personal relationship with print: more } \\
\text { pleasurable, relaxing and comfortable } \\
\text { Working between multiple screens } \\
\text { Copyright and author licence }\end{array}$ \\
\hline Availability & $\begin{array}{l}\text { Instant delivery after acquisition } \\
\text { Multiple concurrent users } \\
\text { Increasing number of titles }\end{array}$ & $\begin{array}{l}\text { Multiple platforms } \\
\text { Different file types } \\
\text { Need for standards }\end{array}$ \\
\hline Currency & Updating of information & $\begin{array}{l}\text { eReader costs } \\
\text { Development costs of publisher } \\
\text { Equity issues } \\
\text { Need for investment in skills development }\end{array}$ \\
\hline Flexibility & $\begin{array}{l}\text { Tailored (personalised) content } \\
\text { Taking notes } \\
\text { Highlighting } \\
\text { Conversion in audio format }\end{array}$ & $\begin{array}{l}\text { Demands on publisher to provide more } \\
\text { bells and whistles }\end{array}$ \\
\hline $\begin{array}{l}\text { Navigation and } \\
\text { readability }\end{array}$ & $\begin{array}{l}\text { Searchability } \\
\text { Variable fonts }\end{array}$ & $\begin{array}{l}\text { Less autonomy for academics } \\
\text { Requires interaction with platforms }\end{array}$ \\
\hline Pedagogy & $\begin{array}{l}\text { Student active engagement } \\
\text { Independent learning } \\
\text { Self-regulated learning } \\
\text { Online and blended learning } \\
\text { Networking } \\
\text { Social Media, WEB2.0 }\end{array}$ & $\begin{array}{l}\text { New skills and attitudes for own learning } \\
\text { New instructional models } \\
\text { New pedagogical strategies } \\
\text { New learning design approach } \\
\text { New educational technologies } \\
\text { New learning methodologies }\end{array}$ \\
\hline Language & $\begin{array}{l}\text { Translations } \\
\text { Glossaries } \\
\text { Metadata }\end{array}$ & $\begin{array}{l}\text { Multiliteracies } \\
\text { Digital natives versus digital immigrates }\end{array}$ \\
\hline $\begin{array}{l}\text { Costs and } \\
\text { security }\end{array}$ & Potentially cheaper than print & $\begin{array}{l}\text { Theft of devices with access codes } \\
\text { Users may have multiple devices, but digi- } \\
\text { tal textbook could be accessible of one } \\
\text { Hardware: non-biodegradable, batteries. }\end{array}$ \\
\hline $\begin{array}{l}\text { Environmental } \\
\text { issue }\end{array}$ & $\begin{array}{l}\text { No paper } \\
\text { No ink } \\
\text { No obsolete older editions }\end{array}$ & Academic/publishing companies' interests \\
\hline
\end{tabular}




\section{Future Research Direction and Conclusions}

The modern digital textbook design is assumed to be the coherent product of an author and users of content. The MetaSystems thinking approach involve design and development of the cognitive, affective and psychomotor frameworks. This means that author of the digital textbooks need to think not only about the content, but also about the interfaces, learning styles, how the users will access graphics, assessment tasks etc. Moreover, it is important to estimate the consistencies of screen design, changing colours, font sizes, etc. on different digital devices, as well as to estimate the learning outcomes.

The user interface design needs to be more than an instructional or assessment design. According to Klir (1990, p. 325), meta X are used as the name of things or systems, which are more than $\mathrm{X}$ in sense than it is more organised, have higher logical type of organisation and it is analysed in more general case.

Our hypothesis is:

if a digital content contains hypertext or multimodal text, it can be personalised. However, this content should be integrated in a feedback loop with immediate and delayed feedback and will contain a concept mapping tool that will assure a powerful learning environment.

Metasystems approach to learning design relies on post-modernism philosophy of learning, architecture of integrative structure of competence, user interface design principles and learner-centered learning environment. Moreover, conceptual modelling and Data visualization criteria is based on the following principles: principle of self-regulation (the automatic regulation of learning processes through activation of metacognition using didactical and psychological methods, cybernetics techniques and management systems); principle of personalisation (the individualization of learning objects through increased formation of the individual as a self and as a member of global learning community); principles of feedback diversity (electronic educational context needs to be evaluated through immediate and delayed feedback); principle of clarity (the formation of structural skeleton content with powerful interconnected concepts); principle of dynamism and flexibility (the learner' active inclusion in elaboration of the content in order to provide the competence development skills) and the principle of ergonomics (computer based learning and computer based assessment is guided by ergonomic interfaces and ergonomic places of work.

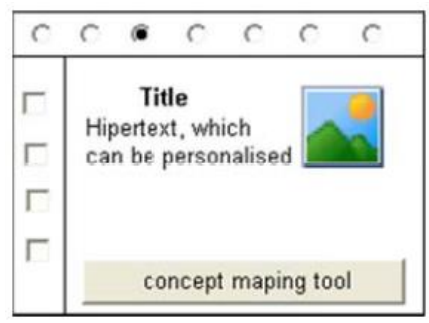

Fig. 3. The user interface design according to MetaSystem Learning Design approach. 
Analysing the metasystems approach to learning design as educational outcomes of learning, we realised that the evolution of informational technologies conduct to metasystems thinking as an output in learning with electronic textbook. This result is achieved when user interface design criteria provide the evidence of the interdependences between information /communication, cognitive and assessment processes. Future research can be conducted on analysis and development of metasystem thinking based on integrated structure of competences with savoir-vivre architecture according to students' cognitive and metacognitive development in real and virtual learning environments. This type of the architectures integrates savoir-dire, savoir-faire and savoir-être components.

The modeling of savoir-vivre architecture for digital textbook will reflect the input, output, and transitional states of the cognitive systems in concordance with time, knowledge and skills. This includes the psychological, physiological and attitudinal characteristics of learner.

\section{Reference}

Atkinson, P., Bayar, G., Kroters, A. (1969). Introduction to Mathematic Theory of Learning. Moscow, Mir. (In Russian).

Barker J., Tucker, R. (1990). The Interactive Learning Revolution. New York, London-Nichols Publishing.

Barron, A. (1990). Complexity regularization with applications to artificial neural networks. In: Roussa, G. (ed.), Nonparametric Functional Estimation. 561-576.

Blum, L.F., Cucker, F., Shub, M., Smale. S. (1998). Complexity and Real Computation. Springer-Verlag.

Brandstädter, K. (2012). Assessing system thinking through different concept mapping practices. International Journal of Science Education, 34(14), 2147-2170.

Brusilovsky, P, Peylo, C. (2003). Adaptive and intelligent Web-based educational systems. International Journal of Artificial Intelligence in Education, 156-169.

Brusilovsky, P., Schwarz, E., Weber, G. (1997). Electronic textbooks on WWW: from static hypertext to interactivity and adaptivity. In: B.H. Khan (ed.). Web-based Instruction. Educational Technology Publications, Englewood Cliffs, New Jersey, 255-261.

Bush, R.R., Mosteller, F. (1951). A mathematical model for simple learning. (Reprinted from Psychological Review. 58, 313-323). In: Fienberg S.E., Hoaglin D.C. (Eds.), Selected Papers of Frederick Mosteller. Springer, New York (2006), 221-234.

http://link.springer.com/chapter/10.1007\%2F978-0-387-44956

Carl, B., Stephani, I. (1990). Entropy, Compactness and the Approximation of Operators. Cambridge University Press.

Darrow R. (2012). What Does it Look Like to be a Blended Learning Teacher?

http://www.slideshare. net/robdarrow/blended-learning-what-does-it-looklike-for-a-teacher

Edmunds, D., Triebel, H., (1996). Function Spaces, Entropy Numbers, Differential Operators. Cambridge University Press.

Ellsworth, N.J., Hedley, C.N., Baratta, A.N. (1994). Literacy: A Redefinition. Lawrence Erlbaum Associates, Philadelphia.

Few, S. (2013): Data visualization for human perception. In: Soegaard, M.D., Rikke, F. (Eds.). The Encyclopedia of Human-Computer Interaction, 2nd ed. The Interaction Design Foundation, Aarhus, Denmark.

https://www.interaction-design.org/encyclopedia/data_visualization_for human perception.html

Huba, F. (2000). Comparison of teacher-centered and learner-centered paradigms.

http: //assessment.uconn. edu/docs/TeacherCenteredVsLearnerCenteredParadigms.pdf

Khutorskoi, A.V. (2006). The place of the textbook in the didactic system. Russian Education and Society, 48(3), 78-93. (In Russian).

Klir, G. (1990). Architecture of Systems Problem Solving. New York and Longon, Plenum Press. (In Russian). 
Lazanski, T.J. (2010). Systems thinking: ancient Maya's evolution of consciousness and contemporary systems thinking. In: AIP Conference Proceedings. 1303(1), 289-296.

Merrill, M.D., Drake, L., Lacy, M.J., Pratt, J., ID2_Research_Group. (1996). Reclaiming instructional design. Educational Technology, 36(5), 5-7. http://mdavidmerrill.com/Papers/Reclaiming.PDF Norman, M.F. (1972). Marcov Processes and Linear Models. New York, Academic Press.

Open Lab Space (2013). What is Multimodality?

http: // labspace. open.ac.uk/mod/oucontent/view.php?id=445539\&section=4. 1

Railean E. (2012). Issues and challenges associated with the design of electronic textbook. In: Khan B.H. (Ed.), User Interface Design for Virtual Environments: Challenges and Advances. Hershey, PA, IGI Publishing, 238-256.

Railean E. (2012). Trends, issues and solutions in e-books pedagogy. In: Tiong-Thye Gon, Boon-Chong Seet, Pei-Chen Sun (Eds.), E-Books \& E-Readers for E-Learning. Orauariki: Victoria Business School. 154-196.

Risku, M., Harding, L. (2013). A unified theory. In: Risku, M., Harding, L. Education for Tomorrow: A Biocentric, Student-Focused Model for Reconstructing Education. SensePublishers, 113-134.

Solway, D. (2011). On hypertext, or back to the Landau. Academic Questions, 24(3), 341-350.

Wang, W., Zhai, J. (2013). Multi-disciplinary internet-based platform in optimizing college English teaching. In: International Conference on Information, Business and Education Technology (ICIBIT 2013). $1037-1042$.

E. Railean, $\mathrm{PhD}$ in science of Education, is an Assistant Professor at the University of European Studies of Moldova and senior researcher at Academy of Sciences of Moldova. She wrote more than 60 articles in theory and methodology of learning. Research interests include philosophy of learning, knowledge management, quantum psychology and mathematical modeling. Elena Railean is author of monograph Methodology of educational software, 5 IGI book chapters, including Knowledge Management Model for Electronic Textbook Design (in Enterprise Resource Planning Models for the Education Sector: Applications and Methodologies, K. K. Patel (Ed.)) and Issues and challenges associated with the design of electronic textbook (in B.H. Khan (Ed.), User Interface Design for Virtual Environments: Challenges and Advances). Her visions about digital pedagogy were published in E-Books \& E-Readers for E-Learning (in Tiong-Thye Gon, Boon-Chong Seet, Pei-Chen Sun (Eds.)).

\section{Žmogaus sąsajos su kompiuteriu ir duomenų vizualizavimo kriterijai skaitmenininiams vadovèliams projektuoti}

\section{Elena RAILEAN}

Žmogaus sąsajos su kompiuteriu ir duomenų vizualizavimo kriterijai yra ypač svarbūs projektuojant skaitmeninius vadovèlius. Vis dèlto, taikant mokymosi proceso matematinị modeliavimą galimų sprendimų analizei, pastebimi skirtingi rezultatai. Matematinis modeliavimas remiasi statistika ir tikimybiu teorija, grafų teorija, neuroniniais tinklais ir kt. Tačiau mokymosi projektavimo metodologijos grindžiamos biheviorizmo, kognityvizmo, konstruktyvizmo ir konektyvizmo teorijomis. Biheviorizmas tiria elgesị, tačiau visa atsakomybè už mokymąsi perkeliama mokytojams ir (arba) vadovèlių turiniui. Kognityvioji ir socialinè psichologija sukuria pridedamają vertę sistemų teorijai ir atsakomybę suteikia mokinių kognityviųjų sistemų mentalinėms struktūroms. Konstruktyvizmas siekia apimti daugialypes realybės perspektyvas ir interpretacijas, žinių konstravimą, įvairu kontekstą, patirtimi grịstas ir didaktiką akcentuojančias veiklas. Konektyvizmo modeliai grindžiami mentaliniais arba bihevioristiniais fenomenais, kai tarp paprastų vienetų atsiranda tarpusavyje susiję tinklai. Šie procesai gali būti analizuojami tiesinių sistemų ir metasistemų aspektu. Šiame straipsnyje pateikiama žmogaus sąsajos su kompiuteriu ir duomenų vizualizavimo kriterijų apžvalga, kuria siekiama pristatyti metasistemomis grịstą skaitmeninių vadovèlių projektavimą, kūrimą ir naudojimą. 